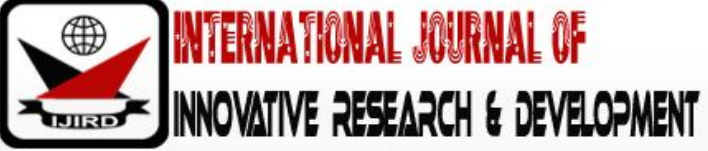

ISSN 2278 - 0211 (Online)

\section{Studies of Fish Species Diversity in Gubi Reservoir, Bauchi State, Nigeria}

Suleiman Maigari
M.Sc. Student, Department of Biological Science,
Abubakar Tafawa Balewa University, Nigeria
Ahmad Jibrin Nayaya
Ezra Abalis Gaya
Professor, Department of Biological Science, Abubakar Tafawa Balewa University, Nigeria
Professor, Department of Biological Science, Abubakar Tafawa Balewa University, Nigeria

\section{Abstract:}

This study is aimed at assessing the fish species diversity in Gubi Reservoir, Bauchi state Nigeria. It was carried out for a period of six months (October 2017-Match 2018). Thirty-six thousand five hundred and sixty-six $(36,566)$ fishes, comprising eight (8) species belonging to six families were examined from fishers using different fishing gears include gill net, cast net, hooks, burgi net and maley net. The fishes were further identified. The species identified include, Clarias garipienus, Oreochromis niloticus, Distichodus engycephalus, Hemichromis fasciatus, Raiamas senegalensis, Labeo senegalensis, Schilbe mystus and Brycinus nurse were caught and identified. Oreochromis niloticus (70.1\%) was the most abundant fish species while Raiamas senegalensis $(0.01 \%)$ was the least fish species abundant. The species richness (R) was higher in kumi, than any other sampling sites Conservation measures is encouraged.

Keywords: Fish species, diversity, Gubi reservoir

\section{Introduction}

Freshwater ecosystems are among the most dynamic and diverse ecosystems and are estimated to maintain over 10,000 species of fish (Nelson, 1994). Nigeria is blessed with over 14 million hectares of reservoirs, lake, ponds and major rivers able of producing over 980,000 metric tons of fish annually (FDF, 2003). Statistical surveys have shown that the need for fish in the country exceeds supply also; domestic production is still very low, in view of the increasing human population. Production from aquaculture is growing compare to artisanal sources and supplied between 5-22\% of total domestic fish production between 2000 and 2007 (FDF, 2007). This increasing production is not capable to meet up the growing rate of consumption because of the wide gap between fish demand and supply, which is on the increase as a result of population outburst in the country in the recent years (Falaye and Jenyo Oni, 2009). Fishes are also play an importance role for the supply as much as 17\% of the world's animal protein (Olusola and Arawomo, 2008).Gubi reservoir is one of such numerous reservoirs in the country not primarily constructed for fisheries purposes, but could serve as a potential water body for fish production. Justification of the study: Aquatic environment become a major habitat for waste disposal, planting of crops, fishing, washing and bathing etc. These have a major impact on water quality as well as fish species diversity. Fish species diversity served as a bio indicator, bio accumulation and bio remediation. The aim of this study is to assess the fish species diversity in Gubi reservoir Bauchi State. The objective of this study is to determine the fish diversity in Gubi reservoir.

\section{Material and Method}

\subsection{Description of Study Site}

Gubi reservoir has a total surface area of $590 \mathrm{~km}^{2}$, a depth of $27 \mathrm{~m}$, top crest width of $10 \mathrm{~m}$, base width of $190 \mathrm{~m}$ and has a total catchment area of $179 \mathrm{~km}^{2}$. the surface of the water in Gubi reservoir is mainly coming from three tributaries namely, Gubi river, tagwaye river, link with shadawanka and ran river, is located at firo a village about $12 \mathrm{~km}$ north east of Bauchi metropolis and $8 \mathrm{~km}$ off Bauchi Maiduguri road. The primary purpose of providing potable water to Bauchi and its environs. A part from improving water supply to the populace, it provides the bulk of fish consumed in the town as well as providing suitable sites for fadama farming resulting in the production of some highly favoured selected crops (Ezra and Nwankwo 2001). The reservoir lies within the boundary of longitude $10^{\circ} 25^{\prime} \mathrm{N}$ to $10^{\circ} 26^{\prime} \mathrm{N}$ and latitude $9051^{\prime} \mathrm{E}$ to $9^{\circ} 52^{\prime}$ E (Wufem et al 2009). 


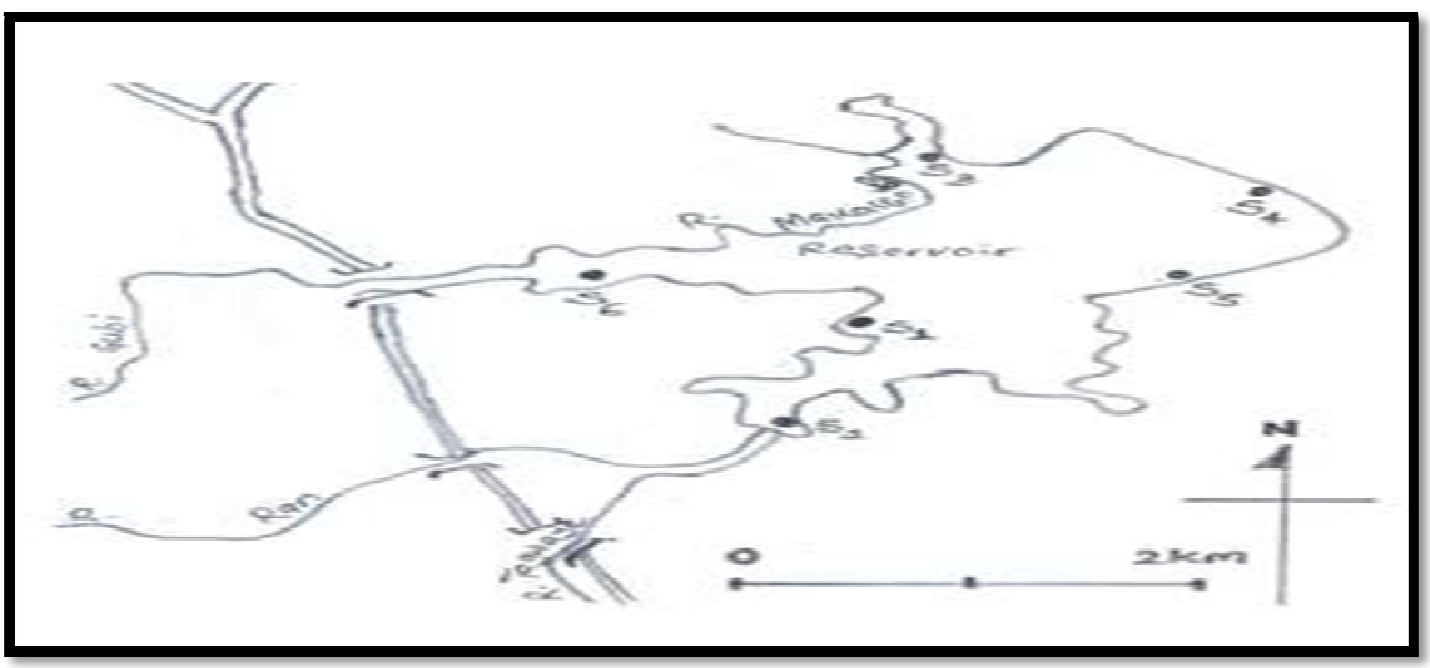

Figure 1: Gubi Reservoir with Its Four Feeding Rivers

\subsection{Sample Collection}

Six sampling sites have been established based on the reconnaissance visit in the study area. The established sampling sites are

- $\quad$ Site $1=$ tatumare

- $\quad$ Site $2=$ kumi

- $\quad$ Site $3=$ baila

- $\quad$ Site $4=$ spillway

- Site $5=$ babban kwata

- Site $6=$ kwatan yashi

\subsection{Fish Sampling and Identification}

Fish was collected fortnightly from each sampling site for a period of six months with the help of fishermen. Different fishing gears include cast net, gill net, clap net, hook net, burgi net and maley net were used during this study. Collection took place in the morning. Identification of fish has been carried out by using keys following the method described by (Idodo- umeh 2003) and (Froese and Pauly, 2015). Fish were identified and sorted out into different species. The relative abundance of each species was expressed as percentage of total catch. Digital Sony camera was used to capture the photos of different fish species, model no. dsc/ wc610.

\subsection{Biological Indices}

To assess the fish diversity, biological indices was used to calculate the statistical analysis this includes;

\subsubsection{Shannon Wiener Diversity Index $\mathrm{H}^{\prime}$}

This can be used to measure the fish diversity it was calculated by the following equation as given by (Magurran 2004). $H^{\prime}=-\sum \mathrm{Pi}(\mathrm{In}(\mathrm{Pi}))$ where $\mathrm{Pi}$ is the proportion of each species in the sample

\subsubsection{Margalef's Diversity Index}

This can be used to measure the species richness in the lake reported by (Clifford and Stephenson 1975). Using the following formula.

$$
\mathrm{d}=\frac{S-1}{\operatorname{InN}}
$$

Where: $\mathrm{d}=$ Species richness index;

$\mathrm{S}=$ Number of species in the population.

$\mathrm{N}=\mathrm{T}$ tal number of individuals of all species.

\subsection{Statistical Analysis}

- One-way Anova was used to compare the composition of fish species between the sampling sites.

- The result obtained was analyzed using descriptive statistics, at $0.05 \%$.

\section{Result}

The result on the studies on fish diversity in Gubi reservoir, Bauchi State, Nigeria was presented below. A total of eight (8) species of fish belonging to six (6) families were identified and recorded during the study period from October 2017 to match 2018. The family of Cichlidae was represented by two species: Oreochromis nilotica and Hemichromis fasciatus. And the family of Cyprinidae were represented by two species: Raiamas senegalensis and Labeo senegalensis, (Table 1). 


\begin{tabular}{|c|c|c|c|}
\hline Species & Family & English name & Hausa name \\
\hline Clarias gariepinus & Claridae & North African catfish & Tarwada \\
\hline $\begin{array}{c}\text { Distichodus } \\
\text { engycephalus }\end{array}$ & Dischodontidae & Grass eater & Kursa \\
\hline $\begin{array}{c}\text { Oreochromis niloticus } \\
\text { Hemichromis } \\
\text { fasciatus }\end{array}$ & Cichlidae & Nile tilapia & Karfasa \\
\cline { 2 - 4 } & & Banded jewel fish & Harshen shanu \\
\hline $\begin{array}{c}\text { Raiamas senegalensis } \\
\text { Labeo senegalensis }\end{array}$ & Cyprinidae & Silver fish & Lakki \\
\cline { 2 - 4 } Schilbe mystus & Achilbeidae & African Butter Catfish & Lulu/ nalanga \\
\hline Brycinus nurse & Alestidae & Nurse Tetra & Kawara \\
\hline
\end{tabular}

Table 1: Fish Species Caught and Identified in Gubi Reservoir

Sources of Local Names; Idodo-Umeh (2003); Olaosebikan and

Raji (1998) and Pauly and Froese (2014)

The result from the study in Table 2, Shows the relative abundance of fish species in Gubi reservoir. A total of thirty-six thousand five hundred and sixty-six of fishes were examined from the fisher's base on the number of sampling sites. Oreochromus niloticus was the most abundance fish species with the overall relative abundance of (70.1\%) showing the prolific nature of tilapia. However, the species of Raiamas senegalensis was the least species abundance with the relative abundant $(0.01 \%)$.

\begin{tabular}{|c|c|c|c|c|c|c|c|}
\hline Fish Species & Tatumari & Kumi & Ba'ila & B/ Kwata & K/ Yashi & Spillway & $\begin{array}{l}\text { Overall Relative } \\
\text { Abundance }\end{array}$ \\
\hline $\begin{array}{l}\text { Oreochromis } \\
\text { niloticus }\end{array}$ & $\begin{array}{c}4596 \\
(70.6 \%)\end{array}$ & $\begin{array}{c}9721 \\
(75.1 \%)\end{array}$ & $\begin{array}{c}4814 \\
(73.3 \%)\end{array}$ & $\begin{array}{c}1446 \\
(44.6 \%)\end{array}$ & $\begin{array}{c}2471 \\
(59.7 \%)\end{array}$ & $\begin{array}{c}2596 \\
(81.9 \%)\end{array}$ & $25644(70.1 \%)$ \\
\hline $\begin{array}{c}\text { Distichodus } \\
\text { engycephalus }\end{array}$ & $\begin{array}{c}247 \\
(3.79 \%) \\
\end{array}$ & $\begin{array}{c}112 \\
(0.86 \%) \\
\end{array}$ & $\begin{array}{c}126 \\
(1.92 \%) \\
\end{array}$ & $\begin{array}{c}40 \\
(1.24 \%) \\
\end{array}$ & $\begin{array}{c}88 \\
(2.13 \%)\end{array}$ & $\begin{array}{c}59 \\
(1.86 \%)\end{array}$ & $672(1.84 \%)$ \\
\hline Brycinus nurse & $\begin{array}{c}55 \\
(0.85 \%) \\
\end{array}$ & $\begin{array}{c}102 \\
(0.78 \%)\end{array}$ & $\begin{array}{c}261 \\
(3.97 \%)\end{array}$ & $\begin{array}{c}201 \\
(6.21 \%)\end{array}$ & $\begin{array}{c}99 \\
(2.39 \%)\end{array}$ & $\begin{array}{c}98 \\
(3.09 \%)\end{array}$ & $816(2.23 \%)$ \\
\hline $\begin{array}{c}\text { Clarias } \\
\text { gariepinus }\end{array}$ & $\begin{array}{c}65 \\
(0.99 \%)\end{array}$ & $\begin{array}{c}51 \\
(0.39 \%)\end{array}$ & $\begin{array}{c}29 \\
(0.44 \%)\end{array}$ & $\begin{array}{c}39 \\
(1.20 \%)\end{array}$ & $\begin{array}{c}40 \\
(0.96 \%)\end{array}$ & $\begin{array}{c}26 \\
(0.82 \%)\end{array}$ & $250(0.68 \%)$ \\
\hline Schilbe mystus & $2(0.03 \%)$ & $4(0.03 \%)$ & $1(0.02 \%)$ & $2(0.06 \%)$ & 0 & 0 & $9(0.02 \%)$ \\
\hline $\begin{array}{c}\text { Raiamas } \\
\text { senegalensis }\end{array}$ & 0 & $1(0.01 \%)$ & $1(0.02 \%)$ & 0 & 0 & 0 & $2(0.01 \%)$ \\
\hline $\begin{array}{c}\text { Labeo } \\
\text { senegalensis }\end{array}$ & $\begin{array}{c}31 \\
(0.47 \%)\end{array}$ & $3(0.02 \%)$ & $9(0.14 \%)$ & $\begin{array}{c}16 \\
(0.49 \%)\end{array}$ & 0 & $\begin{array}{c}4 \\
(0.13 \%)\end{array}$ & $63(0.17 \%)$ \\
\hline $\begin{array}{l}\text { Hemichromis } \\
\text { fasciatus }\end{array}$ & $\begin{array}{c}1506 \\
(23.2 \%)\end{array}$ & $\begin{array}{c}2957 \\
(22.8 \%)\end{array}$ & $\begin{array}{c}1327 \\
(20.2 \%)\end{array}$ & $\begin{array}{c}1493 \\
(46.1 \%)\end{array}$ & $\begin{array}{c}1441 \\
(34.8 \%)\end{array}$ & $\begin{array}{c}386 \\
(12.2 \%)\end{array}$ & $9110(24.9 \%)$ \\
\hline Total & 6502 & 12951 & 6568 & 3237 & 4139 & 3169 & $36566(100)$ \\
\hline
\end{tabular}

Table 2: Relative Abundance of Fish Species in Gubi Reservoir

Table3 indicates the relative Abundance and Diversity indices of fish species at various sampling sites in Gubi dam. The maximum number of Shannon-wiener diversity index $\left(\mathrm{H}^{\prime}\right)$ was recorded in kumi with highest number of individual species (21.8633) with eight numbers of species. While the minimum value of Shannon wiener diversity index was recorded in spillway with the least number of individual species (3169) consists of six species of fish.

\begin{tabular}{|c|c|c|c|c|}
\hline $\begin{array}{c}\text { Sampling } \\
\text { Sites }\end{array}$ & $\begin{array}{c}\text { Number } \\
\text { of Species }\end{array}$ & $\begin{array}{c}\text { Number Of Individuals } \\
\text { Species. }\end{array}$ & $\begin{array}{c}\text { Shannon wiener Diversity } \\
\text { Index (H') }\end{array}$ & $\begin{array}{c}\text { Margalef } \\
\text { Species Richness } \\
\text { Index (D) }\end{array}$ \\
\hline Tatumari & 7 & 6502 & 4.2749 & 0.6834 \\
\hline Kumi & 8 & 12951 & 21.8633 & 0.8093 \\
\hline Ba'ila & 8 & 6568 & 2.0679 & 0.7964 \\
\hline B/ Kwata & 7 & 3237 & 1.0377 & 0.7424 \\
\hline K/Yashi & 5 & 4139 & 0.8930 & 0.4803 \\
\hline Spiilway & 6 & 3169 & 0.6492 & 0.6204 \\
\hline
\end{tabular}

Table 3: Relative Abundance and Diversity Indices of Fish Species at Various Sampling Sites

\section{Discussion}

The result from study had indicated that there were Six (6) families consisting of eight (8) species of fishes which were observed and identified base on the number of sampling sites for the period of six months from October 2017 to Match 2018. This means that the reservoir is rich in ichthyofauna when compare to other water bodies. The result of this study agrees with the finding of (Nazif and Abubakar, 2013), where they have identified fifteen (15) species of fish 
representing eleven (11) families in dadin Kowa Dam Gombe State. While the result of this study Disagrees with the finding of (Lamai and Kolo, 2003), where they have identified five (5) species of fish representing four (4) families in DanZaria dam. The result of this study Disagrees with the findings of (Ekeanyanwu, 1980) in river delmi jos where seven (7) genera were identified, Anthony et al. (1986) recorded four (4) species in Auree reservoir near plateau state. The result from this study agrees with the finding of (White, 1991). Where he identified Eleven (11) species in lake Botsumtwi, Ghana. Abdullahi (2005) reported 26 species were identified in river Benue around Boronji area. Dankishiya (1991) identified 31 species in lake Geriyo. Akanbi (2011) identified 26 species in Ogun estuary, Ogun state, Nigeria.

The relative abundance of fish species indicated that Nile tilapia (Cichlidae) $(70.1 \%)$ was highest abundant species follow by Clarias garipinus (Claridae) $(0.68 \%)$, Silver fish $(0.17 \%)$ Schilbaidae $(0.02 \%)$, where Cyprinidae $(0.01 \%)$ was the least species abundant due to the fact of fishing pressure currently in the reservoir.

Ita (1993) and Adeosun et al. (2011), who were noted that the Mormyridae, Cichlidae, Mochokidae, Characidae, Bagridae and Clariidae were more common in northern Nigeria.

Allison and Okadi (2013) also reported that these six families of fish were common during their study on the Lower Nun River; they suggested that variation in mesh size may have influenced the catches. The dominance of cichlids by number observed in this study is similar to the observations of Akinyemi (1987) on Eleiyele River and Olaniran (2003) on ITA water body; they both reported Cichlidae was the dominant family and suggested that this could be due to their ability to utilize a wide range of foods at the lower trophic level as herbivores, as well as their high fecundity and prolific nature. Komolafe et al. (2016), reported Food and high reproductive efficiency might be responsible for the abundance of the cichlids. Moses (1974) suggested that the dominance of cichlids in Lower Nun River may be attributed to gear selectivity. Also agree with the remarks made by the authors. The abundance of Cichlids and mormyrids could be as a result of fish processing around the Dam which make these fish thrive better. the abundance of fish species showed the Oreochromis niloticus (70.1\%) were the dominant species, followed by Hemichromis fasciitis $(24.9 \%)$, Brycinus nurse $(2.23 \%)$ then Distichodus engycephalus (1.84\%). This agrees with the findings of Akinyemi (1987) in Eleiyele River, that the families Cichlidae and Alestidae were dominants and occurred throughout their study period. The cichlids, Oreochromis niloticus were dominants in similar studies conducted in Lakes Kainji and Tatabu, in Niger State, by Daddy et al. (1991) and Ita (1993), respectively. Daddy et al (1991) and Ita (1993) suggested that their great numbers could be attributed to their high reproductive ability.

The Shannon-wiener diversity index $\left(\mathrm{H}^{\prime}\right)$ for fish species from Gubi reservoir were within the period of study which ranged of 0.6492 to 21.8633 as pointed out by Magurran (2004). The value obtained here are lower than those reported by (Offem et al, 2011) for fish of the Ikwori Lake in south-eastern Nigeria in the rainy season and also for three areas along the Anambra River as reported by Odo, Didigwu and Eyo (2009). Also, Emmanuel and Modupe (2010) reported value of Shannon wiener diversity $\mathrm{H}^{\prime}$ ranging from 1.869 to 2.015 in three tributaries of river Ore which are lower than those reported in this study. The difference can be attributed to disparity in ecological zone. The value for $\mathrm{H}^{\prime}$ both the monthly and by sampling sites indicated a good spread of species diversity in Gubi reservoir. The species richness index (d) of Gubi dam is lower than those reported for three tributaries of the Anambra river by (Odo et al, 2009). This is attributable to the different in number of species encountered. Hence Anambra River is richer in species than Gubi dam. This measure is however not sensitive to environmental disturbances hence, it cannot be absolutely concluded that this value differs for both areas which are in different ecological zones.

The maximum value of Shannon wiener diversity index $\left(\mathrm{H}^{\prime}=21.8633\right)$ with a highest number of individual fish species (12951) with eight number of species were recorded in Kumi, this could be as a result of less anthropogenic activities which probably favour the diversity of fish species around this sampling site. While the minimum value of Shannon wiener diversity $\left(H^{\prime}=0.6492\right)$ with a least number of individual fish species (3169) were recorded in spillway, this could be attributed to present of anthropogenic activities around this sampling site.

\section{Conclusion}

At least a total of eight (8) species of fish belonging to six (6) families were identified and recorded during the study period from October 2017 to match 2018. The Oreochromis nilotica (70.1\%) was the highest fish species while Raiamas senegalensis(0.01) was the least species abundance.

\section{Recommendations}

Licensing should be introduced so that any individual without a fishing license will be prevented from fishing. This will help to reduce the number of participants in the fishery.

Size limits should be set for the fish caught. This will reduce overfishing and ensure that immature individuals are not caught.

The findings of this study should serve as base line information in assisting the government in the management and conservation of the fish species diversity in Gubi Reservoir.

\section{References}

i. Abdullahi M. (2005).Diversity and abundance of fish species in River Benue-Boronji,area. B.

ii. Anthony, A. O., Enerience G., and Ufodike, E. B .C (1986). Studies on the fish fauna of Auree reservoir Plateau State. Nigeria Journal of Applied Fisheries and Hydrobiology, volume 1. Pp15-16.

iii. Allison, M. E. and Okadi, D. (2013). Gill Net Selectivity, Seasonal, Tidal and Photoperiod Variation in Catch in Lower Nun River, Niger Delta, Nigeria. Science Resources Essays, 8:108-114. 
iv. Adeosun, F. I, Omoniyi, Y., Akegbejo-Samson, Y. and Olujimi, O. O. (2011). The fishes of Ikere Gorge drainage system in Ikere, Oyo State, Nigeria. Asiatic Journal of Biotechnology Resources, 2(4): 374-383.

v. Akanbi, A.A. (2011): Catch assessment, fish species diversity and abundance in Ogun estuary, Ogun state, Nigeria. B.Sc. Project. University of Agriculture Abeokuta, Nigeria. Pp 28.

vi. Akinyemi, O. (1987). Fishing Activities and Fish Species Diversity Assessment in Eleiyele River, Ibadan, Nigeria. African Journal of Livestock Extension, 2: 72-74.

vii. Dankishiya, A. S. (1991). Species diversity of fishes in Lake Geriyo, Yola, Gongola State. B. Tech. Project, F.U.T. Yola. $72 \mathrm{pp}$

viii. Daddy, F. M. Osuamkpe, A. and Mohammed, A. (1991). Wetland Studies. Natural Resources Evaluation of Lake Tatabu (Ndakolowu), New-Bussa, Nigeria National Institute for Freshwater Fisheries Research Report, pp. 50-60

ix. Ezra, A. G. And Nwankwo, D.I. (2001). Composition of phytoplankton algae in gubi dam reservoir, bauchi state nigeria. Journal of aquatic science, 16:115-118

x. Ekeanyanwu, A. A (1980): A survey of macro invertebrates and fish fauna in relation to water quality in Delmi River Jos. B.Sc. Thesis Zoo dept. Uni-Jos Nigeria.

xi. Emmanuel, L.O. and Modupe, O. O. (2010). Fish diversity in three tributaries of River Ore, South West, Nigeria. World Journal of Fisheries and Marine Science 2/ 6.524 - 531.

xii. Federal Department of Fisheries (FDF) (2003). Presidential Forum on Fisheries and Aquaculture (Status and Opportunities). Federal Department of Fisheries Report, Abuja, Nigeria. P.49

xiii. Federal Department of Fisheries (FDF) (2007). Fisheries statistic of Nigeria. fourth edition1995-2007.49pp.

xiv. Falaye, A. E. and Jenyo-Oni, A. (2009). Aquatic biodiversity and the implication in artisanal fishing production. African journal of livestock extension, 7:39

xv. Ita, E. O. (1993). Inland Fishery Resources of Nigeria. Central institute of Fresh water Aquaculture Occasional Paper. 20:120-126

xvi. Idodo-Umeh, G. (2003). Freshwater fishes of Nigeria. (taxonomy, ecological notes, sddiet and utilization). IdodoUmeh Publishers Ltd., Benin City, 232pp.

xvii. Komolafe, O.O., Olofinmehinti, M. O., Adedeji, A. A. and Adewole, H. A. (2016). The Distribution Composition and Abundance of Fish Species in two Abandoned Gold Mine Resources IGun, Osun State, Nigeria. Ife Journal of Science Vol. 18 no.1

xviii. Lamai, S. L. and Kolo, R.J. (2003). Biodiversity and abundance of fish and plankton of Dan-Zaria Dam, Niger State, Nigeria.Journal of Aquatic Science 18/ 2. 141 - 148-43

xix. Magurran, A. E (2004). Measuring Biological Diversity. Blackwell publishing carlton, victoria, Australia. 256pp

xx. Moses, O. O. (1974). Aspect of the Biology of Asejire Reservoir. Ph. D. Thesis, University of Ibadan, Nigeria. 301pp.

xxi. Magurran, A. E (2004). Measuring Biological Diversity. Blackwell publishing carlton, victoria, Australia. 256pp

xxii. Nelson, J. S. (1994). Fishes of the World.3rd Edition, John Wiley and Sons, Inc. New York. 600pp

xxiii. Nazif, S. and Abubakar, U. M. (2013). Diversity and Condition Factors of Fish Species of Dadin kowa Dam, Gombe State Nigeria Green journal of Biological sciences 3(10) 350-356.

xxiv. Olusola, O. K. and Arawomo, G. O. A. (2008). Preliminary Observations on Fish Species in a Newly Impounded Osinmo Reservoir. Turkish. Journal of Fisheries and Aquatic Science, 8: 289-292

xxv. Olaniran, T. S. (2003). Fishing Activities and Fish Species Diversity Assessment in Eleiyele Lake, Ibadan, Nigeria. African Journal of Livestock Extension, 2: 72-74

xxvi. Odo, G. E, Didigwu, N. C. and Eyo, J. E. (2009). The fish fauna of Anambra river basin, Nigeria: species abundance and morphometry. Revista de Biologia Tropical (Int.J. Trop. Biol.). 57/ 1-2. 177 - 186.

xxvii. Offem, B. O., Ayotunde, E.O. Ikpi, G. U., Ochang, S. N. and Ada, F. B. (2011). Influence of seasons on water quality, abundance of fish and plankton species of Ikwori Lake, South-Eastern Nigeria. Fisheries and Aquaculture Journal.13.1-18

xxviii. Pauly, D. (1993). Linear Regressions in Fisheries Research. Journal of the fisheries research, Canada, 30: 409-434.

xxix. Wufem, B. M., Ibrahim, A. Q., Gin, N. S., Mohammed, M. A., Ekanem, E. O, and Shibdawa, M. A. (2009). Speciation of heavy metals in the sediments of gubi dam bauchi state, Nigeria. Global journal of environmental science, $8(2): 55-63$

xxx. Whyte, S. A. (1975): Distribution, trophic relationship and breeding habits of the fish populations in a tropical lake Basin. (Lake Bosuntwi-Ghana). Reprinted from Journal zoo. London vol. 177. Pp25-56 


\section{Appendix}

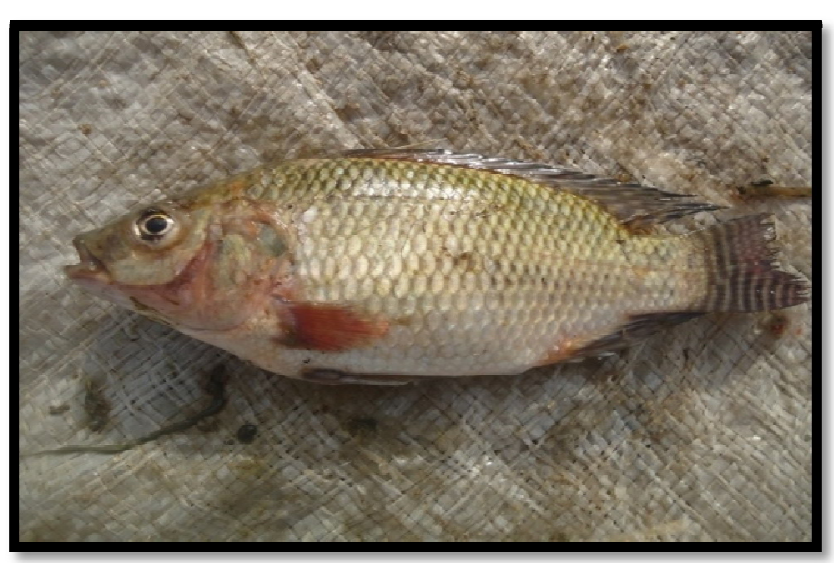

Figure 2: Lateral View Oforeochromis Niloticus

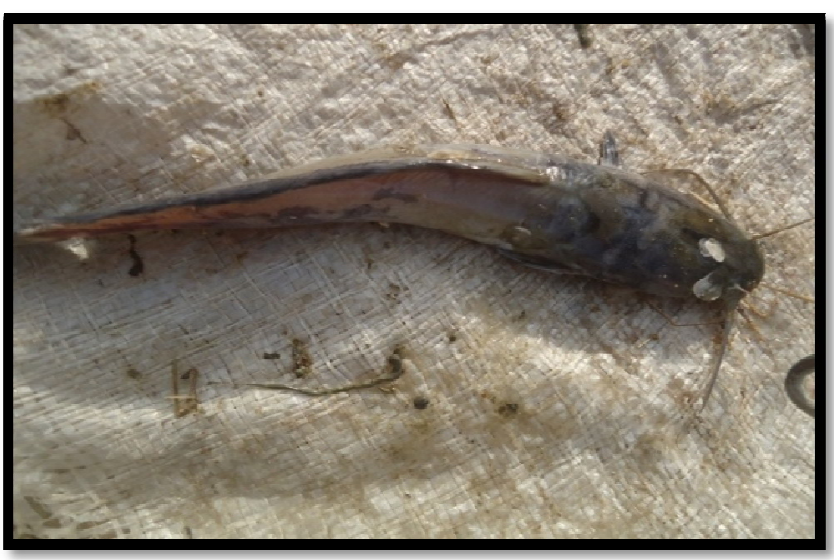

Figure 3: Dorsal and Lateral View of Clarias Gariepinus

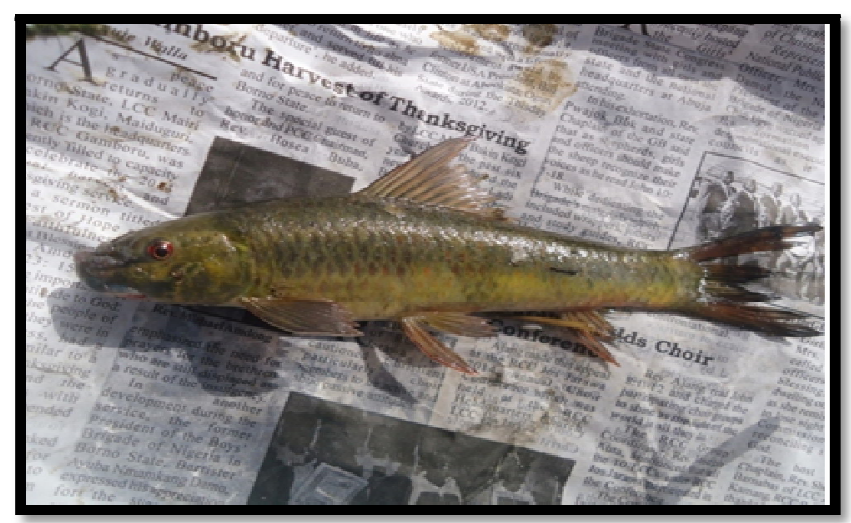

Figure 4: Lateral View Oflabeo Senegalensis

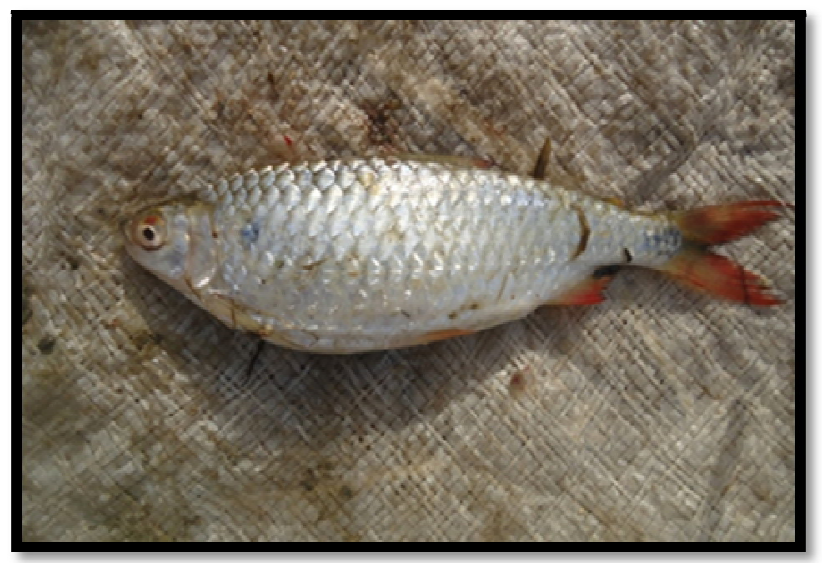

Figure 5: Lateral View Ofbrycinus Nurse 


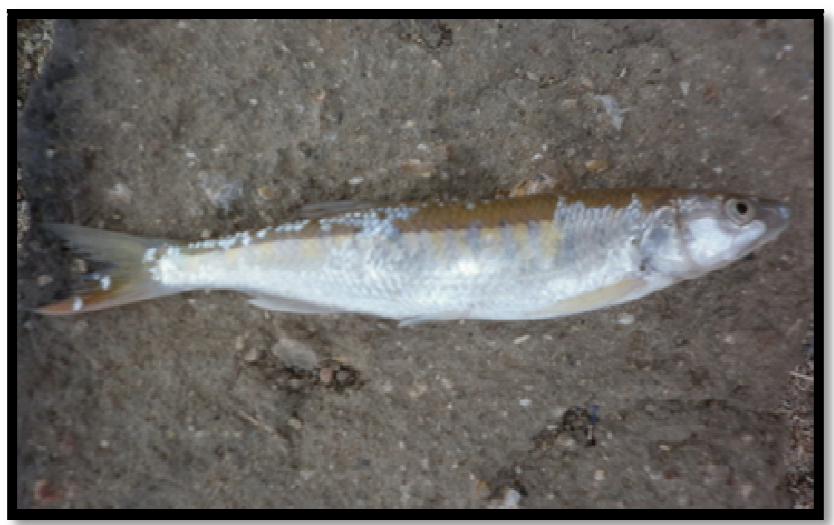

Figure 6: Lateral View of Raiamas Senegalensis

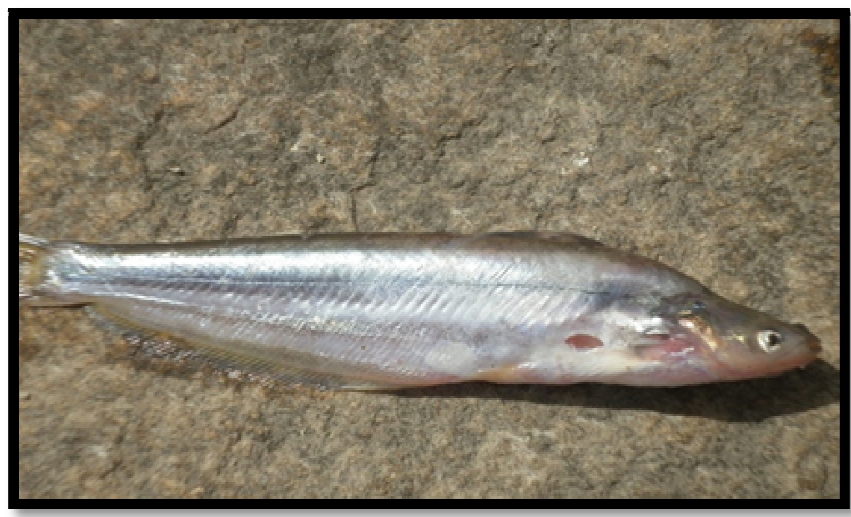

Figure 7: Lateral View of Schilbe Mystus

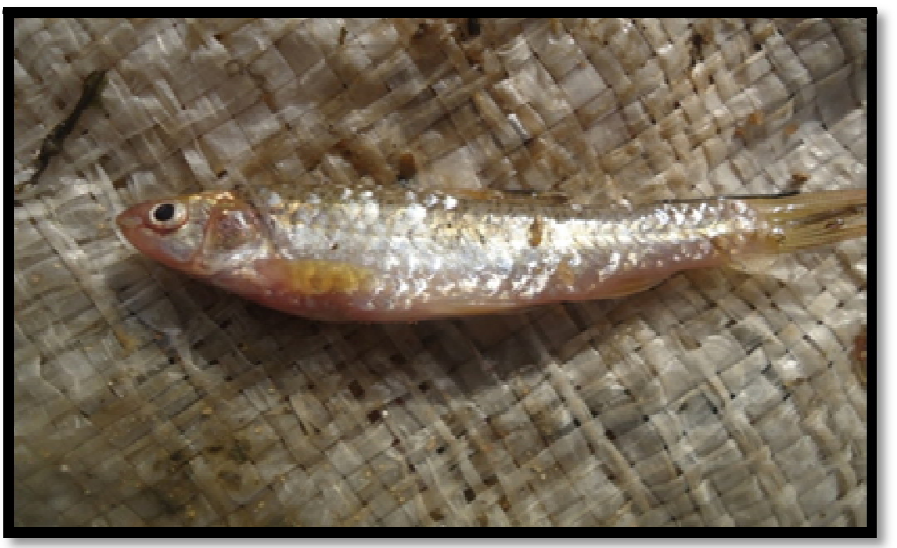

Figure 8: Lateral View of Distichodus Engycephalus

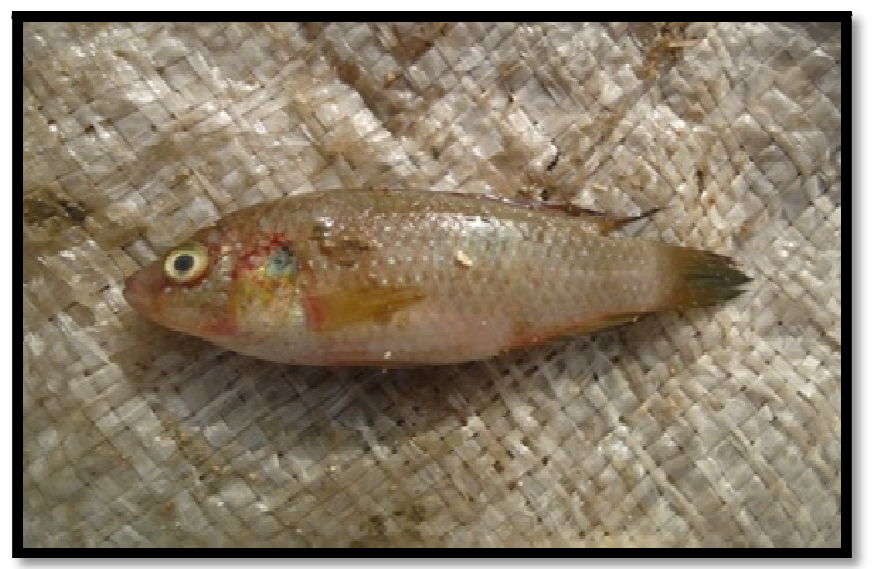

Figure 9: Lateral View of Hemichromis Fasciatus 